\title{
Uric Acid and Renal Function
}

\author{
Guilherme Ambrosio Albertoni, Fernanda Teixeira Borges and Nestor Schor \\ Department of Medicine, Nephrology Division, Federal University of São Paulo \\ (UNIFESP) \\ Brazil
}

\section{Introduction}

Since the discovery of hyperuricemia as the cause of gout in the early 1800s, hypertension, cardiovascular disease and kidney disease have also been related to increased serum uric acid (UA) levels in subsequent years (Nakagawa et al., 2006); patients with gout had a much higher prevalence of hypertension (25-50\%), mild-to-moderate kidney disease (20-60\%) (Kutzing \& Firestein, 2008) and cardiovascular disease (90\%) compared to the general population. However, conflicting results regarding the role of UA as the causative factor in diseases other than gouty arthritis resulted in a shift of interest away from UA. In recent years, uric acid regained the lost popularity due to new findings in a number of disease states including hypertension, renal disease, metabolic syndrome and many more (Feig et al., 2008).

Hyperuricemia arises from excess dietary purine or ethanol intake, decreased renal excretion of UA, or from tumor lyses in lymphoma, leukaemia, or solid tumours (Kutzing \& Firestein, 2008). Finally, several drugs alter UA handling by the kidney, for example drug therapy with candesartan (Li et al., 2008) or both loop- and thiazide diuretics, all of which increase the net urate reabsorption (Suliman et al., 2006). In the majority of individuals, hyperuricemia will be asymptomatic, but as UA tends to precipitate in tissues and in other body fluids, persistent hyperuricemia may eventually lead to the accumulation of urate crystals in many places, resulting in either acute painful conditions, like gout/tophaceous gout/gouty arthritis, urolithiasis, or, in severe cases, like tumor lysis syndrome, in acute UA nephropathy (Riegersperger et al., 2011).

In recent years, increased fructose intake, particularly via sweetened beverages, started to attract more attention from the medical community. During the last two centuries, at least in the western world, dietary fructose intake dramatically increased, with corresponding increases in serum UA levels (Feig et al., 2008). The increase in fructose intake and hyperuricemia is now being associated to the development of metabolic syndrome.

Hyperuricemia is associated with an increased risk for developing CKD (Obermayr et al., 2008) and a risk factor for renal dysfunction in patients with rheumatoid arthritis (Daoussis et al., 2009). Retrospective data suggest an influence of hyperuricemia on graft loss after kidney transplantation (Haririan et al., 2010). A screening among 18,020 individuals with chronic kidney diseases (CKD) found a $20.6 \%$ prevalence of hyperuricemia. A cross-sectional study in individuals aged over 40 years found $10.5 \%$ prevalence of CKD, and among these, 26\% were hyperuricemic (Shan et al., 2010). A 
multi-center study of 2,145 consecutive patients with essential hypertension found a prevalence of hyperuricemia of $35 \%$ in males and $43 \%$ in females, and this was associated with elevated serum creatinine levels (Lin et al., 2010). A screening among 5,722 individuals found a 5.4\% incidence of chronic kidney disease, and serum UA (sUA) correlated with serum creatinine levels (Chen et al., 2009). A cross-sectional study in 9,375 participants of a health-screening program found $14.5 \%$ hyperuricemic individuals (Kuo et al., 2010). A screening study found a higher incidence of end-stage renal disease among hyperuricemic women (Iseki et al., 2004), and a post-hoc analysis in 294 patients initiating renal replacement therapy found that half of these were hyperuricemic with a twofold increase in mortality when UA levels were $\geq 9.0 \mathrm{mg} / \mathrm{dL}(\geq 535 \mu \mathrm{mol} / \mathrm{l})$ (Suliman et al., 2006).

\section{Uric acid metabolism}

UA is the end-product of purine nucleotide metabolism in humans. In contrast to many lower vertebrates, human lack UA oxidase (uricase), an enzyme which further catalyses UA to allantoin, more soluble end product (Sautin \& Johnson, 2008). Humans have higher serum UA levels when compared to other mammals due to the lack of uricase (Johnson et al., 2003). UA is primarily excreted via the urine. The balance between dietary intake, endogenous metabolism of purines and the urinary excretion rate of UA determines plasma UA levels (Kutzing \& Firestein, 2008).

Almost all serum UA is present in the ionized form, monosodium urate, and only about $5 \%$ of urate is protein bound at physiological $\mathrm{pH}$. The definition of hyperuricemia is currently arbitrary and varies from $>6 \mathrm{mg} / \mathrm{dL}(360 \mu \mathrm{mol} / \mathrm{l})$ in women and $>7 \mathrm{mg} / \mathrm{dL}(416 \mu \mathrm{mol} / \mathrm{l})$ in men, to $\geq 6.5 \mathrm{mg} / \mathrm{dL}(387 \mu \mathrm{mol} / \mathrm{l})$, or to $>8.3 \mathrm{mg} / \mathrm{dL}(494 \mu \mathrm{mol} / \mathrm{l})$, regardless of gender. UA levels physiologically and gradually rise during the human lifetime; in female individuals, UA levels additionally rise after menopause (Hak et al., 2008).

Renal handling. Kidneys eliminate two-thirds, and the gastrointestinal tract eliminates one-third of the UA load. Urate is filtered completely at the renal glomerulus. However, the normal fractional excretion of UA is only $8 \%$ to $12 \%$. Therefore, postglomerular reabsorption and secretion are the ultimate factors regulating the amount of UA excretion (Gutman et al., 1968; Steele et al., 1973). The proximal tubule is the site of UA reabsorption and secretion. Almost complete reabsorption of urate occurs at the S1 segment of the proximal tubule. However, in the S2 segment of the proximal tubule urate is secreted at a range greater than reabsorption via transporters URAT1, OAT1, -2 , and $-3,-4$, and -10 , the multi-drug resistance proteins ABCC4 and ABCG2, and the glucose transporters GLUT 9a and $b$, and others. Finally, post-secretory resorption occurs at a more distal site of the proximal tubule. Approximately $10 \%$ of the filtered urate appears in the urine (Shekarriz et al., 2002).

UA Chemistry. UA is a weak acid with 2 dissociation constants. Two factors contribute to UA solubility: UA concentration and solution $\mathrm{pH}$. However, the solubility of UA in urine is primarily determined by urinary $\mathrm{pH}$. The first $\mathrm{pKa}$ of $\mathrm{UA}$ is at a $\mathrm{pH}$ of 5.5 , resulting in the loss of 1 proton from UA and the formation of anionic urate (Finlayson, 1974). The second pKa is 10.3 , which has no physiological significance in humans. The supersaturation of urine with UA occurs when urinary $\mathrm{pH}$ is less than 5.5 . In contrast, at a $\mathrm{pH}$ of more than 6.5 the majority of UA is in the form of anionic urate. The solubility of urate salts is affected by the relative concentrations of cations present in the urine. Increased urinary sodium 
concentrations promote formation of the monosodium urate complex, which is more soluble than undissociated UA. Urine is frequently supersaturated with sodium urate but stones of this type are infrequent. However, supersaturation with sodium urate may contribute to calcium oxalate stone formation via heterogeneous nucleation.

UA pool. UA may be derived by endogenous or exogenous routes. The endogenous production of UA from purine synthesis, and tissue catabolism under normal circumstances, is relatively constant at 300 to $400 \mathrm{mg}$ per day. However, the exogenous pool varies significantly with diet. A diet rich in animal protein contributes significantly to the purine pool and subsequent UA formation by a series of enzymatic reaction involving xanthine oxidase as the final step.

Excretion. Renal excretion is the primary mode of UA clearance, accounting for two-thirds of its elimination. Intestine, skin, hair and nails account for the remaining one-third of UA excretion. In the intestine bacteria catabolise UA into carbon dioxide and ammonia, which are then eliminated as intestinal air or absorved and excreted in the urine.

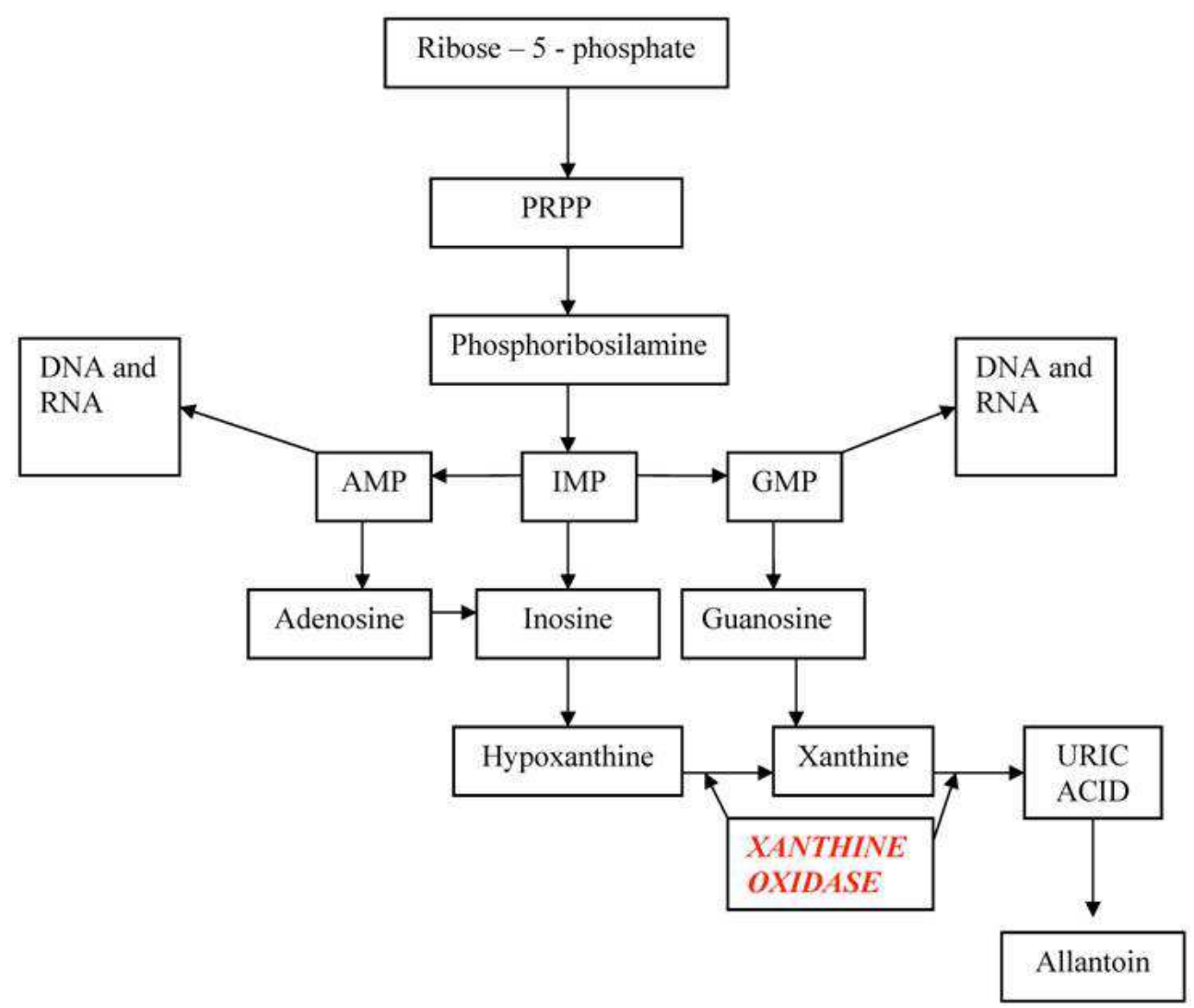

Fig. 1. Schematic representation of the metabolism of Uric Acid 


\section{Mechanisms of uric acid-induced hypertension}

It is well established that when UA is deposited in tissues in the crystalline form, it initiates a proinflammatory state, as seen in gouty arthritis (Sanchez-Lozada et al., 2006). However, the precise pathogenetic role of soluble UA in the serum is somewhat less clear. Moreover, markedly elevated serum UA is clearly associated with gouty arthritis and nephrolithiasis, whereas the importance of subtle elevation in UA levels still remains to be established.

For many years, UA was regarded as a metabolically inert substance. However, several lines of evidence have demonstrated that soluble UA is a strong antioxidant (Ames et al., 1981).

Despite these well-recognized antioxidant effects, UA also behaves as a pro-oxidant and proinflammatory factor. A few points should be emphasized to better understand this apparent paradox. First, UA acts differently inside the cells or in the extracellular milieu, where it is present in soluble form. While being a potent antioxidant in extracellular fluid, UA exerts pro-oxidative effects once inside the cell (Sautin et al., 2007; Corry et al., 2008; Convento et al., 2011).

Second, one isoform of xanthine oxidoreductase - xanthine dehydrogenase - undergoes extensive phenotypic conversion to xanthine oxidase under local ischemic conditions. Unlike xanthine dehydrogenase, xanthine oxidase uses molecular oxygen instead of Nicotinamide Adenine Dinucleotide (NAD) as an electron acceptor (Glantzounis et al., 2005).

In addition to interference with free radical production, UA has some direct effects on endothelial and smooth muscle cells of the vascular wall, which ultimately lead to endothelial dysfunction (Mazzali et al., 2002). In endothelial cells, UA blocks nitric oxide (NO) release, inhibits endothelial proliferation and stimulates C-reactive protein production (Khosla et al., 2005). Several experimental studies also showed that UA can activate smooth muscle cells via activation of specific MAP kinases, nuclear transcription factors, stimulation of ciclooxigenase-2 (Cox-2), and various inflammatory mediators such as the tissue renin-angiotensin system (Corry et al., 2008; Watanabe et al., 2002; Kang et al., 2002). Recent evidence also suggests that hyperuricemia increased cellular proliferation, angiotensin II (AII) and endothelin-1 (ET-1) in human mesangial cells (Albertoni et al., 2010), which could contribute to reduce GFR.

In a landmark study by Mazzali et al., 2001 pharmacologically induced mild-to-moderate hyperuricemia via oxonic acid administration in rats resulted in the development of hypertension. Conversely, when UA elevation was treated with allopurinol or with a uricosuric agent, development of hypertension could be prevented. Other experimental studies show that at a concentration of $10 \mathrm{mg} / \mathrm{dL}$ UA significantly decreases the production of ET-1 in mesangial cells after $24 \mathrm{~h}$ of treatment. This effect was blocked by Losartan (LOS), an AII receptor type 1 antagonist (Albertoni et al, 2010).

It is also possible that genetic polymorphisms of transporters or enzymes involved in UA metabolism affect blood pressure, especially in younger subjects. For example, hypertension has been associated with polymorphisms of xanthine oxidoreductase (Chaves et al., 2007).

\section{Uric acid and acute renal failure}

Uric acid, as the end-product of purine metabolism in humans, presents a clinical impact since its has a relative insolubility, particularly in the acidic environment of the distal nephron. As a result, states of enhanced purine catabolism increases the urate load on the kidney, leading to intrarenal precipitation. Major causes of increases on purine metabolism 
are malignancies with rapid cell turnover, such as leukemia and lymphomas, and the added acceleration of cell lyses that occurs with chemotherapy and radiation. Serum urate levels rise rapidly, and acute renal failure occurs as a consequence of tubular deposition and obstruction of urate and uric acid. The keys to the diagnosis of acute uric acid nephropathy are the appropriate clinical settings as cell lyses increases, oliguria, marked hyperuricemia, and hyperuricosuria. A urinary uric acid-to-creatinine ratio greater than 1 helps to distinguish acute uric acid nephropathy from other catabolic forms of acute renal failure in which serum urate is elevated. Preventive treatment involves pharmacologic xanthine oxidase inhibition with allopurinol and alkaline diuresis. Occasionally, acute renal failure occurs despite allopurinol due to tubular precipitation of the metabolites precursors, such as xanthine, which accumulate with xanthine oxidase inhibition. Dialysis therapy may be required both to correct azotemia and to reduce the body burden of urate. Hemodialysis is preferred since it can achieve greater clearance than other dialysis modes. (Conger, 1990).

\section{Uric acid and kidney disease}

Association of UA with chronic kidney disease dates back to 1890s. Any functional declive which reduces glomerular filtration rates (GFR) and tubular reabsorption secondarily leads to UA elevation, but also the decrease in glomerular filtration rate can increase serum UA (Feig, 2009). To determine which comes first was the principal endeavor of UA researchers in the last two decades.

Experimental studies performed by Mazzali et al., 2002, demonstrated that hyperuricemic rats developed hypertension, afferent arteriolopathy, glomerular hypertrophy, and increased glomerular pressure, tubulointerstitial damage and macrophage infiltration (Mazzali et al., 2002; Sanchez-Lozada et al., 2005; Nakagawa et al., 2003).

Several works analyzed the effects of UA in kidney cells and hyperuricemic animal models. Firstly, hyperuricemia induces endothelial dysfunction and inflammation (Yu et al., 2010, Khosla et al., 2005). UA has the ability to increase monocyte chemoattractant protein (MCP1) in cultured vascular smooth muscle cells (Kanellis et al., 2003) and human proximal tubular epithelial cells (Cirillo et al., 2006). UA can induce the contraction (Albertoni, et al., 2010) and reactive oxygen species produced in mesangial cells (Convento et al., 2011).

\section{Uric acid, metabolic syndrome and diabetes}

The relationship between hyperuricemia, hypertension, and the metabolic syndrome has long been debated. Are the conditions different manifestations of a common underlying metabolic disorder? Is hyperuricemia in part responsible for hypertension? Recent evidences from animal studies and epidemiology suggest that hyperuricemia has a primary role in both hypertension and the metabolic syndrome. Rats that were made hyperuricemic rapidly developed hypertension through activation of the renin-angiotensin system, induction of endothelial dysfunction, and vascular smooth muscle proliferation. Lowering UA in these animals prevented this effect (Johnson et al., 2005). In a longitudinal study in children, there was a strong correlation between hyperuricemia and the subsequent development of hypertension (Feig et al., 2006). Recent epidemiological data suggest also that hyperuricemia is an independent risk factor for developing hypertension. In a group of subjects who did not have the metabolic syndrome, normotensive men with baseline hyperuricemia had $80 \%$ more risk of develop hypertension compared with those who did not have hyperuricemia (Krishnan 
et al., 2007). Finally, the degree of hyperuricemia is strongly correlated with the prevalence of the metabolic syndrome (Yoo et al., 2005; Choi et al., 2007; Facchini et al., 1992).

Metabolic syndrome has many components which may independently mediate or lead to kidney damage, including increased inflammation (Calabro \& Yeh, 2008), insulin resistance and endothelial dysfunction (Kim et al., 2006). Additionally, diets high in fructose constitute one of the major predisposing factors for the metabolic syndrome epidemia (Cirillo et al., 2006). Fructose is unique among sugars by its ability to rapidly deplete ATP, with resultant purine nucleotide degradation and eventual UA generation.

Experimental studies in rodents have suggested that UA may contribute to the development of the metabolic syndrome, hypertension, and kidney disease (Feig et al., 2008) and recently clinical studies focusing on UA and the development and progression of diabetic kidney disease have been published (Hovind et al., 2011). In the early report of the Modification of Diet in Renal Disease Study (Hunsicker et al., 1997), UA was not found to be an independent predictor for renal disease. Others large epidemiologic studies have revealed conflicting results in this respect. While the majority (Iseki et al., 2001; Domrongkitchaiporn et al., 2005; See et al., 2010; Chang et al., 2010; Obermayr et al., 2008) of these studies suggest an independent predictive role for UA in renal disease, others (Tomita et al., 2000; Sturm et al., 2008; Madero et al., 2009) argue against it.

Historically, the elevated level of UA observed in the metabolic syndrome has been attributed to hyperinsulinemia, since insulin reduces renal excretion of UA (Quinõnes et al., 1995).

Hyperuricemia, however, often precedes the development of hyperinsulinemia (Nakagawa et al., 2005; Carnethon et al., 2003), obesity (Masuo et al., 2003), and diabetes (Nakanishi et al., 2003; Dehghan et al., 2008; Chien et al., 2008). Hyperuricemia may also be present in the metabolic syndrome in people who are not overweight or obese.

The strongest evidence of a role for UA in the development of the metabolic syndrome has been from studies models showing that decreasing UA levels can prevent or reverse features of the metabolic syndrome (Nakagawa et al., 2006; Sanchez-Lozada et al., 2008; Reungjui et al., 2007). Two mechanisms have been suggested to explain how hyperuricemia might induce the metabolic syndrome. The first mechanisms is related to the fact that glucose uptake in skeletal muscle depend in part on increases in blood flow mediated by the insulinstimulated release of NO from endothelial cells. Features of the metabolic syndrome develop in mice lacking endothelial nitric oxide synthase (iNOs) (Cook et al., 2003). The observations that hyperuricemia can induce endothelial dysfunction in rats (Khosla et al., 2005) and that treatment with allopurinol can improve endothelial function in patients with hyperuricemia (Mercuro et al., 2004) would support this mechanism. The second mechanism concerns the inflammatory and oxidative changes UA induces in adipocytes (Sautin et al., 2007), a process that is key in causing the metabolic syndrome in obese mice (Furukawa et al., 2004).

The prevalence of diabetes, and for that matter the associated complications, has increased dramatically. Presently, diabetes is the leading cause of end-stage renal disease in the western world (United States Renal Data System, 2008). Although the progression of renal disease can be halted partially, diabetic nephropathy is still regarded as an irreversible and progressive disease (Parving et al., 2008).

Therefore, it has become increasingly essential to determine the pathophysiological mechanisms underlying the development and progression of diabetic nephropathy. Evidence is available of a complicated interaction between different contributors to the disease process. It is possible that genetic susceptibility, metabolic abnormalities, 
hemodynamic changes, upregulated growth factors, and cytokines may all play a part in the development of diabetic glomerulopathy; however, the complex pathogenesis of development of diabetic nephropathy has not been fully clarified (Hovind et al., 2011).

Recently clinical studies focusing on UA, albuminuria and diabetic kidney disease have been published (Bonakdaran et al., 2011; Kim et al., 2010; Kuo et al., 2010). The new evidence suggests that UA could be a risk factor for the development of diabetic nephropathy; however, the significance of serum UA as pathogenic factor in the development of diabetic nephropathy is not yet fully clarified (Hovind et al., 2011).

\section{Uric acid stones}

A high concentration of urate and low $\mathrm{pH}$ are the determinants of UA stone formation. The prevalence of UA stones in the United States is estimated to be 5\% to 10\% (Gutman et al., 1968). Interestingly, these data originate from studies performed more than 30 years ago. Therefore, the current incidence of UA stones in the United States may be different. In a more recent study from Veterans Administration hospital stone analyses revealed that $12 \%$ of stones contained some UA component and $9.7 \%$ comprised pure UA (Mandel et al., 1989). Incidence also may vary with age. The incidence of UA stones was $11 \%$ in a geriatric population (Gentle et al., 1997). The frequency of UA stones also varies in different geographical locations within the United States. In southern states the incidence has been reported at $4 \%$ compared with $17 \%$ in Chicago (Riese et al., 1992). Other industrialized countries have wide variations in UA stone rates, with Germany reporting $17 \%$ to $25 \%$, Sweden $4 \%$ and Israel up to $40 \%$ (Hesse et al., 1975; Scholz et al., 1979; Grenabo et al., 1985; Atsmon et al., 1963). Urate stones have frequently been reported in Iran and Pakistan. However, the majority of these stones are ammonium acid urate (Minon et al., 1983). These apparent geographical variations indicate that genetic, dietary and environmental factors may have an important role in the formation of UA stones.

Composition and different types of UA stones. UA stones can be classified based on crystalline composition as anhydrous uric acid, uric acid dehydrate, sodium acid urate monohydrate or ammonium acid urate (Halabe et al., 1994). The anhydrous form is thermodynamically the most stable crystal. The dehydrate form is unstable and undergoes dehydration to the anhydrous form. Uric acid dehydrate has been identified in $20 \%$ of UA calculi and may represent the entire component. Ammonium acid urate precipitation requires high urate and ammonium concentrations and occurs at a higher $\mathrm{pH}$. Recently, a classification of UA stones based on their crystalline growth pattern has been suggested (Grases et al., 2000).

Mechanism of stone formation. UA stone formation requires supersaturation of urinary UA. Three factors contribute to the formation of these calculi: acidic urine, hyperuricemia and decreased urinary volume. One or more of these conditions may coexist in a specific patient and contribute to stone disease severity (Shekarriz et al., 2002).

Hyperuricosuria. Hyperuricosuria is defined as a mean 24-hour urinary UA excretion of more than $600 \mathrm{mg} / 24 \mathrm{hr}$ in 2 of 3 collected samples (Pak et al., 1980). Hyperuricosuria may be associated with hyperuricemia, such as in primary gout, or may manifest as an isolated abnormality due to various factors such as diet or medications. The degree of hyperuricemia correlates with the incidence of UA stone formation. In patients with gout the incidence of UA stones was $23 \%$ in those with urinary UA levels less than $600 \mathrm{mg} / 24 \mathrm{hr}$ compared with 
$50 \%$ in those with UA levels greater than $1,000 \mathrm{mg} / 24 \mathrm{hr}$ (Yu et al., 1967). In other study $11 \%$ of patients with UA excretion less than $300 \mathrm{mg} / 24 \mathrm{hr}$ had UA stones (Hall et al., 1967; Katz et al., 1970). In patients with gout the rate of stone formation is higher when uricosuric drugs are administered.

Urinary $\mathrm{pH}$. All conditions contributing to acidic urine promote uric acid stone formation. Urinary $\mathrm{pH}$ is abnormally low in a significant number of patients with gout and in idiopathic UA stone formers (Gutman et al., 1968; Yu et al., 1967; Zechner et al., 1982; Ito et al., 1995). Urinary alkalization is the cornerstone of medical management of UA stones. The concept of UA stone dissolution is not new. Shekarriz et al., 2002 observed impressive dissolution of large burden UA renal stones with oral alkalization. UA stone dissolution by oral alkalization is generally effective, with a reported success rate of $80 \%$ (Shekarriz et al., 2002). Continued alkalization will help prevent future stones, but in the treatment of gout, alkalinization of urine (over $\mathrm{pH}$ 6.5) to maintain the solubility may precipitate calcium phosphate crystals (Meyer et al., 1990).

\section{Gout}

Gout is a disease of ancient origin and its association with UA stones has long been recognized. In 1683 London physician Thomas Sydenham, who suffered from renal stones, described the clinical features of gout. Michelangelo's special interest in anatomy and kidney function has been ascribed to his own urinary stone disease (Eknoyan et al., 2000).

Studies of the composition of urinary calculi were limited before the advent of modern chemistry. Gout is an inflammatory process initiated by tissue deposition of monosodium urate (MSU) crystals. A typical attack is an acute monoarthritis accompanied by classical signs of inflammation. However, inflammation can occur in any tissue in which MSU is deposited, as typified by tophaceous gout and by urate nephropathy due to renal medullary deposition of MSU crystals (So, 2008).

Multiple risk factors may interact and lead to development of gout:

Genetics - Monogenic disorders that result in overproduction of UA via enzyme defects in purine metabolism are extremely rare. Nevertheless, common primary gout in men often shows strong familiar predisposition, although the genetic basis remains unknown. Twin studies have show high heritability for both UA renal clearance $(60 \%)$ and UA: creatinine ratio (87\%) and several susceptibility loci for this have been reported (Roddy et al., 2007).

Gender and age - Men have higher urate levels than women and an increased prevalence of gout at all ages, though less pronounced in older age. Estrogens have a uricosuric effect, making gout very rare in younger women. However, after the menopause, urate levels rise and gout becomes increasingly prevalent. Ageing is an important risk factor in both men and women, possibly due to multiple factors including: an increase in sUA levels (mainly due to reduced renal function); increased use of diuretics and others drugs that raise sUA; age-related changes in connective tissues, which may encourage crystal formation (Roddy et al., 2007).

Diet - Historically, gout has long been linked with a rich lifestyle involving excesses of meat and alcohol, but it is only recently that population studies have been undertaken to determine the risk associated with individual dietary components. Data from the large Health Professionals Follow-up Study (HPFS) have show that the relative risk of gout is higher in people who eat a high red meat diet: the relative risk of a first attack of gout associated with an additional daily portion of meat was 1.21 (95\% CI 1.04, 1.41). Higher 
consumption of seafood was associated with a lesser, but still significant, increase in risk. Diets high in purine-rich vegetables did not increase the risk, while diets high in low-fat dairy products were associated with reduced risk (relative risk with additional daily 0.79; 95\% CI 0.71, 0.87) (Choi et al., 2004).

Alcohol - Some alcoholic drinks are rich in purines, notably beer which contains guanosine. Alcohol is though to increase the risk of gout because the metabolism of ethanol to acetyl CoA leads to adenine nucleotide degradation, resulting in increased formation of adenosine monophosphate, a precursor of UA. Alcohol also raises the lactic acid level in blood, which inhibits UA excretion. In the HPFS, overall the higher the daily alcohol intake, the higher the risk of gout (Choi et al., 2004). However, differences in risk were observed with different alcoholic drinks. Beer had the greatest effect, probably because of its high purine content, then alcohol, whereas wine had no increased risk (Choi et al., 2004).

Drugs - Many drugs which either increase sUA levels (e.g. diuretics and pyrazinamide) or reduces sUA levels (e.g.uricosurics such as benzbromarone, sulphinpyrazone and vitamin C) effect these changes via interaction with urate transporters such as URAT1 (Anzai et al., 2005) and GLUT9 (Caulfield et al., 2008).

RENAL DISEASE AND GOUT - Gout frequently associates with kidney disease, each being a risk factor for the other. Primary kidney disease can lead to hyperuricemia and it has been suggested that the increasing prevalence of end-stage renal disease may be one cause of recent increases in gout (Roddy et al., 2007). Kidney damage secondary to gout is associated with urate crystals and microtophi in the interstitium and/or UA crystals within tubules. Evidence from animal studies suggests that hyperuricemia may accelerate chronic kidney disease, and several studies have demonstrated a significant and independent association between sUA levels and the progression of chronic kidney disease (Kang et al., 2002; Kang et al., 2005). A history of gout is an independent risk factor for urolithiasis in men (Kramer et al., 2003). The increased risk is not just for UA stones, but also for more common calcium phosphate stones. High urinary levels of UA increase the risk of stone formation and in gout patients, the higher the excretion of UA, the greater the risk of stone formation (Yu et al., 1967). However, the most important risk factor for UA stone formation is persistently acidic urine, favoring the precipitation of urate (Shekarriz et al., 2002). In patients with UA stones, a high urinary UA: creatinine ratio indicates overproduction of UA, which should prompt a search for an abnormality of purine metabolism.

\section{Advances in therapy of hyperuricemia and gout}

The treatment of hyperuricemia and gout remains a challenge even though we appear to have a number of effective drugs. Many clinicians recognize that our existing treatment choices are often limited in the routine clinical setting. Allopurinol, the most commonly used drug to treat hyperuricemia, can provoke severe allergic-type reactions and needs to be used with caution in renal failure. Fortunately, the incidence of these rare reactions is low, but skin rashes are frequently reported (Hung et al., 2005). Benzbromarone, a very effective uricosuric drug, was recently withdrawn from general distribution because of a number of cases of hepatic failure associated with its use. Other hypouricemic drugs are therefore needed. Recently, a new xanthine-oxidase inhibitor, febuxostat, underwent clinical trials and was show to be as effective as allopurinol in reducing hyperuricemia (Becker et al., 2005). Febuxostat, unlike allopurinol, is not a purine analog and does not cross-react with allopurinol. In clinical trials, when administered at a daily dose of either 80 or $120 \mathrm{mg}$, it was 
more effective than a $300 \mathrm{mg}$ daily dose of allopurinol in achieving the target value of uricemia (less than $6 \mathrm{mg} / \mathrm{dL}$ or less than $360 \mu \mathrm{mol} / \mathrm{L}$ ), a target that has been recommended in treatment guidelines for gout and hyperuricemia (Zhang et al., 2006).

\section{Conclusion}

It is becoming clear that the role of UA is no longer confined solely to gout and nephrolithiasis. Increasing evidence now points to a significant relation of UA to hypertension and renal disease. Moreover, recent studies have started to unveil the causal nature of this relationship in both hypertension and renal disease. Despite considerable progress, given the numerous confounders, more compelling evidence is needed before ultimately labelling UA as a causative factor in hypertension and renal disease. Persistently acidic urine resulting in supersaturation of UA is the only metabolic abnormality found in many patients with UA stones. Although the mechanism responsible for acidic urine in many patients remains unclear, urinary alkalization is the cornerstone of medical management and should be the primary mode of treatment in the absence of absolute indications for surgical intervention. Furthermore, prophylaxis with urinary alkalization using oral alkali prevents stone recurrence and associated morbidity. Hyperuricemia is the central risk factor for gout and is a key component of the metabolic syndrome, is also an independent risk factor for cardiovascular disease, although at present there is no evidence to support urate-lowering therapy for asymptomatic hyperuricemia. More studies in this exciting and provocative area of research are being conducted and published (Kanbay et al., 2007; 2010; Turgut et al., 2009).

\section{References}

Albertoni G, Maquigussa E, Pessoa E, Barreto JA, Borges F, Schor N. (2010). Soluble uric acid increases intracellular calcium through an angiotensin II-dependent mechanism in immortalized human mesangial cells. Experimetal Biological Medicine, Vol. 235, No.7, (July 2010), pp.825-832, ISSN 1535-3702.

Ames BN, Cathcart R, Schwiers E, Hochstein P. (1981). Uric acid provides an antioxidant defense in humans against oxidant- and radical-caused aging and cancer: a hypothesis. Proccedings of the National Academy of Science USA, Vol. 78, No.11, (November 1981), pp.6858-6862, ISSN 0027-8424.

Anzai N, Enomoto A, Endou H. (2005). Renal urate handling: clinical relevance of recent advances. Curr Rheumatol Rep, Vol. 7, No 3, (June 2005), pp.227-35, ISSN 1534-6307.

Atsmon A, de Vries A, Frank M. (1963). Uric acid lithiasis. New York: Elsevier Publishing Co.

Becker MA, Schumacher HR Jr., Wortmann RL, MacDonald PA, Eustace D, Palo WA, Streit J, Joseph-Ridge N. (2005). Febuxostat compared with allopurinol in patients with hyperuricemia and gout. N Engl J Med, Vol. 353, No 23, (December 2005), pp.245061, ISSN 1533-4406.

Bonakdaran S, Hami M, Shakeri MT.. (2011). Hyperuricemia and albuminuria in patients with type 2 diabetes mellitus. Iranian Journal of Kidney Dieases, Vol. 5, No.1, (January 2011), pp. 21-24, ISSN 1735-8582. 
Calabro P. Yeh ET. (2008). Intra-abdominal adiposity, inflammation, and cardiovascular risk: new insight into global cardiometabolic risk. Current Hypertension Report, Vol. 10, No.1, (February 2008), pp.32-38, ISSN 1522-6417.

Carnethon MR, Fortmann SP, Palaniappan L, Duncan BB, Schmidt MI, Chambless LE. (2003). Risk factors for progression to incident hyperurinsulinemia: the atherosclerosis risk in communities study. American Journal of Epidemiology, Vol. 158, No.11, (December 2003), pp.1058-1067, ISSN 1476-6256.

Caulfield MJ, Munroe PB, O’Neill D, Witkowska K, Charchar FJ, Doblado M, Evans S, Eyheramendy S, Onipinla A, Howard P, Shaw-Hawkins S, Dobson RJ, Wallace C, Newhouse SJ, Brown M, Connell JM, Dominiczak A, Farrall M, Lathrop GM, Samani NJ, Kumari M, Marmot M, Brunner E, Chambers J, Elliott P, Kooner J, Laan M, Org E, Veldre G, Viigimaa M, Cappuccio FP, Ji C, Iacone R, Strazzullo P, Moley $\mathrm{KH}$, Cheeseman C. (2008). SLC2A9 is a high-capacity urate transporter in humans. PLoS Med, Vol. 5, No 10, (October 2008), pp.197, ISSN 1549-1676.

Chang HY, Tung CW, Lee PH, Lei CC, Hsu YC, Chang HH, Yang HF, Lu LC, Jong MC, Chen CY, Fang KY, Chao YS, Shih YH, Lin CL. (2010). Hyperuricemia as an independent risk factor of chronic kidney disease in middle-aged and elderly population. American Journal of the Medical Science, Vol. 339, No.6, (June 2010), pp. 509-515, ISSN 0002-9629.

Chaves FJ, Corella D, Blesa S, Mansego ML, Marín P, Portoles O, Sorlí JV, González-Albert V, Tormos MC, García-García AB, Sáez G, Redon J. (2007). Xanthine oxidoreductase polymorphisms: influence in blood pressure and oxidative stress levels. Pharmacogenetics and Genomics Vol. 17, No.8, (August 2007), pp.589-596, ISSN 17446872.

Chen YC, Su CT, Wang ST, Lee HD, Lin SY. (2009). A preliminary investigation of the association between serum uric acid and impaired renal function. Chang Gung Med J, Vol. 32, No 1, (Jan-Feb 2009), pp.66-71, ISSN 2072-0939.

Chien KL, Chen MF, Hsu HC, Chang WT, Su TC, Lee YT, Hu FB. (2008). Plasma uric acid and the risk of type 2 diabetes in a Chinese community. Clinical chemistry Vol. 54, No.2, (February 2008), pp.310-316, ISSN 0009-9147.

Choi HK, Atkinson K, Karlson EW, Willett W, Curhan G. (2004). Purine-rich foods, dairy and protein intake, and the risk of gout in men. $N$ Engl J Med, Vol. 350, No 11, (March 2004), pp. 1093-103, ISSN 1533-4406.

Choi HK, Willett W, Curhan G. (2007). Coffee consumption and risk of incident gout in men: a prospective study. Arthritis Rheum, Vol. 56, No 6, (June 2007), pp.2049-55, ISSN 1529-0131.

Cirillo P, Sato W, Reungjui S, Heinig M, Gersch M, Sautin Y, Nakagawa T, Johnson RJ. (2006). Uric acid, the metabolic syndrome, and renal disease. Journal of the American Society Nephrology, Vol. 17, No. 12 Suppl, (December 2006), pp. S165-S168, ISSN 1046-6673.

Conger JD. (1990). Acute uric acid nephropathy. Med Clin North Am, Vol. 74, No 4, (July 1990), pp.859-71, ISSN 1557-9859.

Convento MS, Pessoa E, Dalboni MA, Borges FT, Schor N. (2011). Pro-inflammatory and oxidative effects of noncrystalline uric acid in human mesangial cells: contribution to hyperuricemic glomerular damage. Urological Research, Vol. 39, No.1, (June 2010), pp.21-27, ISSN 0300-5623. 
Cook S, Hugli O, Egli M, Vollenweider P, Burcelin R, Nicod P, Thorens B, Scherrer U. (2003). Clustering of cardiovascular risk factors mimicking the human metabolic syndrome X in eNOs null mice. Swiss Med Weekly Vol. 136, No.24-26, (June 2003), pp.360-363, ISSN 1424-3997.

Corry DB, Eslami P, Yamamoto K, Nyby MD, Makino H, Tuck ML. (2008). Uric acid stimulates vascular smooth muscle cell proliferation and oxidative stress via the vascular renin-angiotensin system. Journal of Hypertension, Vol. 26, No.2, (February 2008), pp.269-275, ISSN 0263-6352.

Daoussis D, Panoulas V, Toms T, John H, Antonopoulos I, Nightingale P, Douglas KM, Klocke R, Kitas GD. (2009). Uric acid is a strong independent predictor of renal dysfunction in patients with rheumatoid arthritis. Arthritis Res Ther, Vol.11, No 4, (July 2009), PP.116, ISSN 1478-6362..

Dehghan A, van Hoek M, Sijbrands EJ, Hofman A, Witteman JC. (2008). High serum uric acid as a novel risk factor for type 2 diabetes. Diabetes Care, Vol. 31, No.2, (February 2008), pp. 361-2, ISSN 0149-5992.

Domrongkitchaiporn S, Sritara P, Kitiyakara C, Stitchantrakul W, Krittaphol V, Lolekha P, Cheepudomwit S, Yipintsoi T. (2005). Risk factors for development of decreased kidney function in a southeast Asian population: a 12-year cohort study. Journal of the American Society Nephrology, Vol.16, No.3, (March 2005), pp.791-9, ISSN 10466673.

Eknoyan G. (2000). Michelangelo: art, anatomy, and the kidney. Kidney Int, Vol.57, No 3, (March 2000), pp.1190-201, ISSN 1523-1755.

Facchini F, Chen YD, Hollenbeck CB, Reaven GM. (1991). Relationship between resistance to insulin-mediated glucose uptake, urinary uric acid clearance, and plasma uric acid concentration. The Journal of the American Medical Association, Vol. 266, No.21, (December 1991), pp.3008-3011, ISSN 0098-7484.

Feig DI, Kang DH, Johnson RJ. (2008). Uric acid and cardiovascular risk. New England Journal of Medicine, Vol.359, No.17, (October 2008), pp.1811-1821, ISSN 0028-4793.

Feig DI, Kang DH, Nakagawa T, Mazzali M, Johnson RJ. (2006). Uric acid and hypertension. Curr Hypertens Rep, Vol. 8, No 2, (May 2006), pp.111-5, ISSN 1534-3111.

Feig DI. (2009). Uric acid: a novel mediator and marker of risk in chronic kidney disease? Current Opinion in Nephrology and Hypertension, Vol.18, No.6, (November 2009), pp.526-530, ISSN 1062-4821.

Finlayson B. (1974). Symposium on renal lithiasis. Renal lithiasis in review. Urol Clin North Am, Vol. 01, No 2, (June 1974), pp.181-212, ISSN 1558-318X.

Furukawa S, Fujita T, Shimabukuro M, Iwaki M, Yamada Y, Nakajima Y, Nakayama O, Makishima M, Matsuda M, Shimomura I. (2004). Increased oxidative stress in obesity and its impact on metabolic syndrome. The Journal of Clinical Investigation, Vol.114, No.12, (December 2004), pp.1752-1761, ISSN 0021-9738.

Gentle DL, Stoller ML, Bruce JE, Leslie SW. (1997). Geriatric urolithiasis. J Urol, Vol.158, No 6, (December 1997), pp.2221-4, ISSN 1527-3792.

Glantzounis GK, Tsimoyiannis EC, Kappas AM, Galaris DA. (2005). Uric acid and oxidative stress. Current Pharmaceutical Design, Vol.11, No.32, pp.4145-4151, ISSN 1381-6128.

Grases F, Villacampa AI, Costa-Bauza A, Sohnel O. (2000). Uric acid calculi: types, etiology and mechanisms of formation. Clin Chim Acta, Vol. 302, No 1-2, (September 2000), pp.89-104, ISSN 1873-3492. 
Grenabo L, Hedelin H, Petterson S. (1985). The severity of infection stones compared to other stones in the upper urinary tract. Scand J Urol Nephrol, Vol. 19, No 4, pp.285-9, ISSN 1651-2065.

Gutman AB, Yu TF. (1968). Uric acid nephrolithiasis. Am J Med, Vol. 45, No 5, (November 1968), pp.756-79, ISSN 1555-7162.

Hak AE, Choi HK. (2008). Menopause, postmenopausal hormone use and serum uric acid levels in US women - the third national health and nutrition examination survey. Arthritis Res Ther, Vol. 10, No 5, (September 2008), pp.116, ISSN 1478-6362.

Halabe A, Sperling O. (1994). Uric acid nephrolithiasis. Electrolyte Metab, Vol. 20, No 6, (1994), pp.424-31, ISSN 0378-0392.

Hall AP, Barry PE, Dawber TR, McNamara PM. (1967). Epidemiology of gout and hyperuricemia. A long-term population study. Am J Med, Vol. 42, No 1, (January 1967), pp.27-37. ISSN 1555-7162.

Haririan A, Noguiera JM, Zandi-Nejad K, Aiyer R, Hurley H, Cooper M, Klassen DK, Weir MR. (2010). The independent association between serum uric acid and graft outcomes after kidney transplantation. Transplantation, Vol. 89, No 5, (March 2010), pp.573-9, ISSN 1534-6080.

Hesse A, Schneider HJ, Berg W, Hienzsch E. (1975). Uric acid dehydrate as urinary calculus component. Invest Urol, Vol. 12, No 5, (March 1975), pp.405-9, ISSN 0021-0005.

Hovind P, Rossing P, Johnson RJ, Parving HH. (2011). Serum uric acid as a new player in the development of diabetic nephropathy. Journal of Renal Nutrition, Vol.21, No.1, (January 2011), pp.124-127, ISSN 1051-2276.

Hung HY, Appel LJ, Choi MJ Gelber AC, Charleston J, Norkus EP, Miller ER 3rd. (2005). The effects of vitamin $C$ supplementation on serum concentrations of uric acid: results of a controlled trial. Arthritis Rheum, Vol. 52, No 6, (June 2005), pp.1843-7, ISSN 1529-0131.

Hunsicker LG, Adler S, Caggiula A, England BK, Greene T, Kusek JW, Rogers NL, Teschan PE. (1997). Predictors of the progression of renal disease in the Modification of Diet in Renal Disease Study. Kidney International, Vol.51, No.6, (June 1997), pp.1908-1919, ISSN 0098-6577.

Iseki K, Ikemiya Y, Inoue T , Iseki C, Kinjo K, Takishita S. (2004). Significance of hyperuricemia as a risk factor for developing ESRD in a screened cohort. Am J Kidney Dis, Vol. 44, No 4, (October 2004), pp642-50, ISSN 1523-6838.

Iseki K, Oshiro S, Tozawa M, Iseki C, Ikemiya Y, Takishita S. (2001). Significance of hyperuricemia on the early detection of renal failure in a cohort of screened subjects. Hypertension Research, Vol. 24, No 6, (November 2001), pp.691-697, ISSN 0916-9636.

Ito H, Kotake T, Nomura K, Masai M. (1995). Clinical and biochemical features of uric acid nephrolithiasis. Eur Urol, Vol. 27, No 4, pp.324-8, ISSN 1873-7560.

Johnson RJ, Kang DH, Feig D, Kivlighn S, Kanellis J, Watanabe S, Tuttle KR, RodriguezIturbe B, Herrera-Acosta J, Mazzali M. (2003). Is there a pathogenetic role for uric acid in hypertension and cardiovascular and renal disease? Hypertension, Vol. 41, No 6, (April 2003), pp.1183-1190, ISSN 0194911X.

Johnson RJ, Segal MS, Srinivas T, Ejaz A, Mu W, Roncal C, Sánchez-Lozada LG, Gersch M, Rodriguez-Iturbe B, Kang DH, Acosta JH. (2005). J Am Soc Nephrol, Vol. 16, No 7, (July 2005), pp.1909-19, ISSN 1533-3450. 
Kanbay M, Ozkara A, Selcoki Y, Isik B, Turgut F, Bavbek N, Uz E, Akcay A, Yigitoglu R, Covic A. (2007). Effect of treatment of hyperuricemia with allopurinol on blood pressure, creatinine clearance, and proteinuria in patients with normal renal function. Int Urol Nephrol, Vol. 39, No 4, (August 2007), pp.1227-33, ISSN 1573-2584.

Kanbay M, Sanchez-Lozada LG, Franco M (2010). Microvascular disease and its role in the brain and cardiovascular system: a potential role for uric acid as a cardiorenal toxin. Nephrol Dial Transpalnt, Vol. 26, No 2, (February 2010), pp. 430-7, ISSN 14602385.

Kanellis J, Watanabe S, Li JH, Kang DH, Li P, Nakagawa T, Wamsley A, Sheikh-Hamad D, Lan HY, Feng L, Johnson RJ. (2003). Uric acid stimulates monocyte chemoattractant protein-1 production in vascular smooth muscle cells via mitogen-activated protein kinase and cyclooxygenase-2. Hypertension, Vol. 41, No 6, (May 2003), pp.1287-1293, ISSN 0194911X.

Kang DH, Nakagawa T, Feng L, Watanabe S, Han L, Mazzali M, Truong L, Harris R, Johnson RJ. (2002). A role for uric acid in the progression of renal disease. Journal of the American Society Nephrology, Vol. 13, No 12, (December 2002), pp.2888-2897, ISSN 1046-6673.

Kang DH, Nakagawa T. (2005). Uric acid and chronic renal disease: possible implication of hyperuricemia on progression of renal disease. Sem Nephrol. Vol.25, No 01, (January 2005), pp.43-9, ISSN 1558-4488.

Katz WA, Schubert M. (1970). The interaction of monosodium urate with connective tissue components. J Clin Invest, Vol. 49, No 10, (October 1970), pp.1783-9, ISSN 1365-2362.

Khosla UM, Zharikov S, Finch JL, Nakagawa T, Roncal C, Mu W, Krotova K, Block ER, Prabhakar S, Johnson RJ. (2005). Hyperuricemia induces endothelial dysfunction. Kidney International, Vol. 67, No 5, (May 2005), pp.1739-1742, ISSN 0098-6577.

Kim ES, Kwon HS, Ahn CW, Lim DJ, Shin JA, Lee SH, Cho JH, Yoon KH, Kang MI, Cha BY, Son HY. (2010). Serum uric acid level is associated with metabolic syndrome and microalbuminuria in Korean patients with type 2 diabetes mellitus. Journal of Diabetes and itsComplications, [epub ahead of print], (December 2010), ISSN 10568727.

Kim JA, Montagnani M, Koh KK, Quon MJ. (2006). Reciprocal relationships between insulin resistance and endothelial dysfunction: molecular and pathophysiological mechanisms. Circulation, Vol. 113, No 15, (April 2006), pp.1888-1904, ISSN 00097322.

Krishnan E, Kwoh CK, Schumacher HR, Kuller L. (2007). Hypertension, Vol. 49, No 2, (February 2007), pp.298-303, ISSN 1524-4563.

Kuo CF, Luo SF, See LC, Ko YS, Chen YM, Hwang JS, Chou IJ, Chang HC, Chen HW, Yu KH. (2010). Hyperuricaemia and accelerated reduction in renal function. (2006). Scandinavian Journal of Rheumatology, [Epub ahead of print], (September 2010), ISSN 0301-3847.

Kutzing, MK \& Firestein, BL. (2008). Altered uric acid levels and disease states. Journal of Pharmacology and Experimental Therapeutics, Vol. 324, No 1, (September 2008), pp.1-7, ISSN 0022-3565.

Li Y, Sato M, Yanagisawa Y Mamada H, Fukushi A, Mikami K, Shirasaka Y, Tamai I. (2008). Effects of angiotensin II receptor blockers on renal handling of uric acid in rats. Drug Metab Pharmacokinet, Vol. 23, No 4, (2008), pp.263-70, ISSN 1880-0920. 
Lin CS, Hung YL, Chen GY, Tzeng TF, Lee DY, Chen CY, Huang WP, Huang CH. (2010). A multicenter study of the association of serum uric acid, serum creatinine, and diuretic use in hypertensive patients. Int J Cardiol, Vol. 148, No 3, (May 2010), pp.325-30, ISSN 1874-1754.

Madero M, Sarnak MJ, Wang X, Greene T, Beck GJ, Kusek JW, Collins AJ, Levey AS, Menon V. (2009). Uric acid and long-term outcomes in CKD. Am J Kidney Dis, Vol. 53, No 5, (May 2009), pp.796-802. ISSN 1523-6838.

Mandel NS, Mandel GS. (1989). Urinary tract stone disease in the United States veteran population. II. Geographical analysis of variations in composition. J Urol, Vol. 142, No 6, (December 1989), pp.1516-21, ISSN 1527-3792.

Masuo K, Kawaguchi H, Mikami H, Ogihara T, Tuck ML. (2003). Serum uric acid and plasma norepinephrine concentrations predicts subsequent weight gain and blood pressure elevation. Hypertension, Vol. 42, (October 2003), pp.474-80, ISSN 0194911X.

Mazzali M, Hughes J, Kim YG, Jefferson JA, Kang DH, Gordon KL, Lan HY, Kivlighn S, Johnson RJ. (2001). Elevated uric acid increases blood pressure in the rat by a novel crystal-independent mechanism. Hypertension, Vol. 38, No 5, (November 2001), pp. 1101-1106, ISSN 0194911X.

Mazzali M, Kanellis J, Han L, Feng L, Xia YY, Chen Q, Kang DH, Gordon KL, Watanabe S, Nakagawa T, Lan HY, Johnson RJ. (2002). Hyperuricemia induces a primary renal arteriolopathy in rats by a blood pressure-independent mechanism. American Journal of Physiology. Renal Physiology, Vol. 282, No 6, (June 2002), pp.F991-F997, ISSN 0363-6127.

Mercuro G, Vitale C, Cerquetani E, Zoncu S, Deidda M, Fini M, Rosano GM.. (2004). Effect of hyperuricemia upon endothelial function in patients at increased cardiovascular risk. American Journal of Cardiology, Vol. 94 7, (October 2004), pp. 932-935, ISSN 0002-9149.

Meyer JL. (1990). Physicochemistry of stone formation. Urolithiasis a Medical Surgical Reference, WB Saunders, Philadelphia, pp.11-34.

Minon Cifuentes J, Pourmand G. (1983). Mineral composition of 103 stones from Iran. $\mathrm{Br}$ J Urol,Vol. 55, No 5, (October 1983), pp.468-8, ISSN 0007-1331.

Nakagawa T, Hu H, Zharikov S, Tuttle KR, Short RA, Glushakova O, Ouyang X, Feig DI, Block ER, Herrera-Acosta J, Patel JM, Johnson RJ. (2006). A causal role for uric acid in fructose-induced metabolic syndrome. American Journal of Physiology. Renal Physiology, Vol. 290, No 3, (March 2006), pp. F625-F631, ISSN 0002-9149.

Nakagawa T, Mazzali M, Kang DH, Kanellis J, Watanabe S, Sanchez-Lozada LG, RodriguezIturbe B, Herrera-Acosta J, Johnson RJ. (2003). Hyperuricemia causes glomerular hypertrophy in the rat. American Journal of Nephrology, Vol. 23, No 2, pp. 2-7, ISSN 0250-8095.

Nakagawa T, Tuttle KR, Short RA, Johnson RJ. (2005). Fructose-induced hyperuricemia as a causal mechanism for the epidemic of the metabolic syndrome. Nature Clinical Practice. Nephrology, Vol. 1, No 2, (December 2005), pp. 80-86, ISSN 1745-8323.

Nakanishi N, Okamoto M, Yoshida H, Matsuo Y, Suzuki K, Tatara K. (2003). Serum uric acid and risk for development of hypertension and impaired fasting glucose or type II diabetes in Japanese male office workers. European Journal of Epidemiology, Vol. 18, No 6, pp. 523-30, ISSN 0393- 2990. 
Obermayr RP, Temml C, Gutjahr G, Knechtelsdorfer M, Oberbauer R, Klauser-Braun R. (2008). Elevated uric acid increases the risk for kidney disease. Journal of the American Society of Nephrology, Vol. 19, No 12, (December 2008), pp. 2407-2413 ISSN 1046-6673.

Pak CYC, Britton F, Peterson R, Ward D, Northcutt C, Breslau N, McGuire J, Sakhaee K, Bush S, Nicar M, Norman DA, Peters P. (1980). Ambulatory evaluation of nephrolithiasis. Classification, clinical presentation and diagnostic criteria. Am J Med, Vol. 69, No 1, (July 1980), pp.19-30, ISSN1555-7162.

Parving, H-H. Mauer, M. Ritz E. (2008). Diabetic nephropathy, In: Brenner BM, (ed.) Brenner \& Rector's The Kidney, 8th pp. 1265-1298, Boston

Quiñones Galvan A, Natali A, Baldi S, Frascerra S, Sanna G, Ciociaro D, Ferrannini E. (1995). Effect of insulin on uric acid excretion in humans. American Journal of Physiology. Endocrinology and Metabolism, Vol. 268, No 1, (January 1995), pp. E1-E5, ISSN 01931849.

Reungjui S, Roncal CA, Mu W, Srinivas TR, Sirivongs D, Johnson RJ, Nakagawa T. (2007). Thiazide diuretics exacerbate fructose-induced metabolic syndrome. Journal of the American Society of Nephrology, Vol. 18, No 10, (October 2007), pp. 2724-2731, ISSN 1046-6673.

Riegersperger M, Covic A, Goldsmith D. (2011). Allopurinol, uric acid, and oxidative stress in cardiorenal disease. Int Urol Nephrol, Vol. 43, No 2, (June 2011), pp.441-9, ISSN 1573-2584.

Riese RL, Sakhaee K. (1992). Uric acid nephrolithiasis: pathogenesis and treatment. J Urol, Vol. 148, No 3, (September 1992), pp.765-71, ISSN 1527-3792.

Roddy E, Zhang W, Doherty M. (2007). The changing epidemiology of gout. Nat Clin Pract Rheumatol, Vol. 3, No 8, (August 2007), pp. 443-9, ISSN 1745-8390.

Sánchez-Lozada LG, Nakagawa T, Kang DH, Feig DI, Franco M, Johnson RJ, Herrera-Acosta J. (2006). Hormonal and cytokine effects of uric acid. Current Opinion in Nephrology and Hypertension, Vol. 15, No 1, (January 2006), pp. 30-33, ISSN 1062-4821.

Sánchez-Lozada LG, Tapia E, Bautista-García P, Soto V, Avila-Casado C, Vega-Campos IP, Nakagawa T, Zhao L, Franco M, Johnson RJ. (2008). Effects of febuxostat on metabolic and renal alterations in rats with fructose-induced metabolic syndrome. American Journal of Physiology. Renal Physiology, Vol. 294, No 4, (April 2008), pp.F710-F718, ISSN 0002-9149.

Sánchez-Lozada LG, Tapia E, Santamaría J, Avila-Casado C, Soto V, Nepomuceno T, Rodríguez-Iturbe B, Johnson RJ, Herrera-Acosta J. (2005). Mild hyperuricemia induces vasoconstriction and maintains glomerular hypertension in normal and remnant kidney rats. Kidney International, Vol. 67, No 1, (January 2005), pp. 237-247, ISSN 0098-6577.

Sautin YY \& Johnson RJ. (2008). Uric acid: the oxidant-antioxidant paradox. Nucleosides Nucleotides Nucleic Acids, Vol. 27, No 6, (June 2008), pp.608-19, ISSN 1525-7770.

Sautin YY, Nakagawa T, Zharikov S, Johnson RJ. (2007). Adverse effects of the classic antioxidant uric acid in adipocytes: NADPH oxidase-mediated oxidative/nitrosative stress. American Journal of Physiology. Cell Physiology, Vol. 293, No 2, (April 2007), pp. C584-C596, ISSN 0363-6143.

Scholz D, Schwille PO, Ullbrich D, Bausch WM, Sigel A. (1979). Composition of renal stones and their frequency in a stone clinic: relationship to parameters of mineral 
metabolism in serum and urine. Urol Res, Vol. 7, No 3, (September 1979), pp.161-70, ISSN 1434-0879.

See LC, Kuo CF, Chuang FH, Shen YM, Ko YS, Chen YM, Yu KH. (2010). Hyperuricemia and metabolic syndrome: associations with chronic kidney disease. Clinical Rheumatology, [Epub ahead of print], (April 2010), ISSN 0770-3198.

Shan Y, Zhang Q, Liu Z, Hu X, Liu D. (2010). Prevalence and risk factors associated with chronic kidney disease in adults over 40 years: a population study from Central China. Nephrology, Vol. 15, No 3, (April 2010), pp.354-61, ISSN 1440-1797.

Shekarriz B, Stoller ML. (2002). Uric acid nephrolithiasis: current concepts and controversies. J Urol, Vol. 168, No 4, (October 2002), pp.1307-14, ISSN 1527-3792.

So A. (2008). Developments in the scientific and clinical understanding of gout. Arthritis Res Ther, Vol. 10, No 5, (October 2008), PP.221-27, ISSN 1478-6362.

Steele TH. (1973). Urate secretion in man: the pyrazinamide suppression test. Ann Int Med, Vol. 79, No 5, (November 1973), pp.734-7, ISSN 1539-3704.

Sturm G, Kollerits B, Neyer U, Ritz E, Kronenberg F; MMKD Study Group. (2008). Uric acid as a risk factor for progression of non-diabetic chronic kidney disease? The Mild to Moderate Kidney Disease (MMKD) Study. Experimental Gerontology, Vol. 43, No 4, (April 2008), pp. 347-52, ISSN 0531-5565.

Suliman ME, Johnson RJ, Garcia-Lopez, Qureshi AR, Molinaei H, Carrero JJ, Heimbürger O, Bárány P, Axelsson J, Lindholm B, Stenvinkel P. (2006). J-shaped mortality relationship for uric acid in CKD. Am J Kidney Dis, Vol. 48, No 5, (November 2006), pp.761-71, ISSN 1523-6838.

Tomita M, Mizuno S, Yamanaka H, Hosoda Y, Sakuma K, Matuoka Y, Odaka M, Yamaguchi M, Yosida H, Morisawa H, Murayama T. (2000). Does hyperuricemia affect mortality? A prospective cohort study of Japanese male workers. Journal of Epidemiology, Vol. 10, No 6, (November 2000), pp. 403-9, ISSN 0917-5040.

Turgut F, Kasopoglu B, Kanbay M. (2009). Uric acid, cardiovascular mortality, long-term outcomes in CKD. Am J Kidney, Vol. 54, No 3, (September 2009), pp.582-3, ISSN 1523-6838.

United states renal data system, available at: www.usrds.org, 2008.

Watanabe S, Kang DH, Feng L, Nakagawa T, Kanellis J, Lan H, Mazzali M, Johnson RJ. (2002). Uric acid, hominoid evolution, and the pathogenesis of salt-sensitivity. Hypertension, Vol. 40, No 3, (September 2002), pp. 355-360, ISSN 0194911X.

Yoo TW, Sung KC, Shin HS, Kim BJ, Kim BS, Kang JH, Lee MH, Park JR, Kim H, Rhee EJ, Lee WY, Kim SW, Ryu SH, Keum DG. (2005). Relationship between serum uric acid concentration and insulin resistence and metabolic syndrome. Circ J, Vol. 69, No 8, (August 2005), pp.928-33, ISSN 1347-4820.

Yu MA, Sánchez-Lozada LG, Johnson RJ, Kang DH. (2010). Oxidative stress with an activation of the renin-angiotensin system in human vascular endothelial cells as a novel mechanism of uric acid-induced endothelial dysfunction. Journal of Hypertension, Vol. 28, No 6, (June 2010), pp. 1234-1242, ISSN 0263-6352.

Yu T, Gutman AB. (1967). Uric acid nephrolithiasis in gout. Predisposing factors. Ann Intern Med, Vol. 67, No 6, (December 1967), pp.1133-48, ISSN 1539-3704.

$\mathrm{Yu}$ TF, Gutman AB. (1967). Uric acid nephrolithiasis in gout: predisposing factors. Ann Intern Med, Vol. 67, No 6, (December 1967), pp.1133-48, ISSN 1539-3704. 
Zechner O, Pfluger H, Scheiber V. (1982). Idiopathic uric acid lithiasis: epidemiologic and metabolic aspects. J Urol, Vol. 128, No 6, (December 1982), pp.1219-23, ISSN 15273792.

Zhang W, Doherty M, Pacual E, Bardin T, Barskova V, Conaghan P, Gerster J, Jacobs J, Leeb B, Lioté F, McCarthy G, Netter P, Nuki G, Perez-Ruiz F, Pignone A, Pimentão J, Punzi L, Roddy E, Uhlig T, Zimmermann-Gòrska I. (2006). EULAR evidence based recommendations for gout. Part I: Diagnosis. Report of a task force of the Standing Committee for International Clinical Studies Including Therapeutics (ESCISIT).Ann Rheum Dis, Vol. 65, No 10, (October 2006), pp.1301-11, ISSN 14682060. 


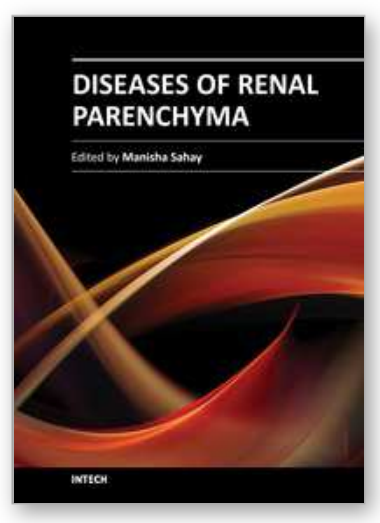

\author{
Diseases of Renal Parenchyma \\ Edited by Prof. Manisha Sahay
}

ISBN 978-953-51-0245-8

Hard cover, 304 pages

Publisher InTech

Published online 16, March, 2012

Published in print edition March, 2012

Clinical nephrology is an evolving speciality in which the amount of information is growing daily. This book gives quick access to some important clinical conditions encountered in nephrology including the diseases of glomeruli, tubules and interstitium. It presents the latest information on pathophysiology, diagnosis and management of important diseases of renal parenchyma. The information is presented in a very user friendly and accessible manner while the treatment algorithms enable the reader to quickly access expert advice on arriving at the most appropriate treatment regimen. The book discusses the renal involvement in various systemic diseases including diabetes and autoimmune diseases. Diabetic nephropathy is fast becoming the commonest cause of end stage renal disease all over the globe and is discussed in this book. The editors believe that this book will be a valuable addition to the reader's library.

\title{
How to reference
}

In order to correctly reference this scholarly work, feel free to copy and paste the following:

Guilherme Ambrosio Albertoni, Fernanda Teixeira Borges and Nestor Schor (2012). Uric Acid and Renal Function, Diseases of Renal Parenchyma, Prof. Manisha Sahay (Ed.), ISBN: 978-953-51-0245-8, InTech, Available from: http://www.intechopen.com/books/diseases-of-renal-parenchyma/uric-acid-and-renal-function

\section{INTECH}

open science | open minds

\section{InTech Europe}

University Campus STeP Ri

Slavka Krautzeka 83/A

51000 Rijeka, Croatia

Phone: +385 (51) 770447

Fax: +385 (51) 686166

www.intechopen.com

\section{InTech China}

Unit 405, Office Block, Hotel Equatorial Shanghai

No.65, Yan An Road (West), Shanghai, 200040, China 中国上海市延安西路65号上海国际贵都大饭店办公楼 405 单元

Phone: +86-21-62489820

Fax: $+86-21-62489821$ 
(C) 2012 The Author(s). Licensee IntechOpen. This is an open access article distributed under the terms of the Creative Commons Attribution 3.0 License, which permits unrestricted use, distribution, and reproduction in any medium, provided the original work is properly cited. 